\title{
MOTOR VEHICLES TAX: SOME PROBLEMS AND EVALUATIONS
}

\author{
Zinnur TUNÇ
}

\begin{abstract}
Motor Vehicle Tax, referred to as a wealth tax in the Turkish tax system, is determined in line with various vehicle types and features according to Law No. 197. With the regulation that came into effect in 2018 , vehicle value is now also taken into consideration in tax base determination in addition to various aspects such as model year, type, engine capacity and weight. Therefore, the ad valorem tariff based on vehicle value has come into practice together with the specific tariff applied before, and a compound tariff structure has been adopted.

However, the fact that no obligation regarding $\mathrm{CO}_{2}$ emission has been included in the new regulation is being criticized with regards to environmental protection in accordance with Article 56 of our Constitution. Considering the total emission by 22,865,921 registered vehicles according to the latest data by the Turkish Statistical Institute, it is clear that the new regulation contains deficiencies with respect to constitutional obligations. The motor vehicle tax, primarily intended to prioritize environmental protection in the European Union, still prioritizes fiscal purposes in Turkey.

Due to all these developments, the issues arising from the new tariff have been discussed and various solutions have been suggested in compliance with the purpose of the study. In addition, the points that are in conflict with taxpayer interests in tariff no. I/A still in effect as part of the new regulation have been discussed, and assessment have been made with regards to taxation principles. Also, practices in the EU and in Turkey have been compared, and similarities between practices in member states have been pointed out to serve as a model.
\end{abstract}

Keywords: Motor Vehicle Tax, Vehicle Value, Environmental Tax, $\mathrm{CO}_{2}$ Emissions

JEL Code: K34, H2O, H23

\section{Introduction}

Motor vehicle tax is one of the wealth taxes in terms of the Turkish taxation system, and has a larger share in tax revenue compared to the inheritance and transfer tax and the real estate tax. From this point of view, motor vehicle tax is one of the instruments that can be used not only for financial purposes, but also for various other purposes. Therefore, it brings several expectations within the context of both literature and legislation. It is subjected to various amendments in order to adapt to new technological developments and international regulations. Regulations brought with the Law No. 7061 are the most recent example to this. Conversion of the tariff structure to a mixed tariff for cars and similar vehicles has caused several new situations to arise.

In this context, the study will elaborate various problems brought by the new regulations in the Motor Vehicle Tax Law No. 197, and explain the deficiencies of the legislation based on examples. In addition to this, connection of the environmental protection duty within the scope of Article 56 of the Constitution with the motor vehicle tax will be discussed, and suggestions will be made for preventing the negative externality caused by the vehicles. In this context,

1 Res. Asst., Istanbul University, zinnurtunc@gmail.com 
motor vehicle tax practices attaching particular importance to environmental protection in the European Union will be explained, and these will be compared with Turkey within the scope of various solution suggestions.

\section{Motor Vehicle Tax in Turkey}

Motor vehicle tax is a direct wealth tax on the registration of motor vehicles listed in the law. It is an objective tax as it does not take into account the personal status of the taxpayers, and it is a specific tax as it is only about the motor vehicles rather than all the elements of wealth (Oktar, 2018: 367).

Taxpayers are subjected to tax according to various tariffs set out in Articles 5 and 6 of the applicable Motor Vehicle Tax Law No. 197. According to these tariff, the tax base is determined based on various factors such as model year, type, engine displacement, maximum total and take-off weight etc.

With a regulation entered into force in 2018, the vehicle value is also added to the specifications to be taken into consideration while determining the tax base. Thus, an ad valorem tariff based on vehicle value in addition to the technical factors such as vehicle's age and displacement has been included to the calculation within the scope of the specific tariff no. (I), and consequently a mixed tariff structure has been introduced (Oktar, 2018: 373). Tariffs no. (I/A), (II) and (IV), however, remain as specific tariffs.

On the contrary to the inheritance and transfer tax among the wealth taxes, motor vehicle tax is a specific wealth tax in terms of scope since it is only limited to motor vehicles, not all the values under the asset (Öz \& Kutbay \& Buzkıran, 2014: 11). Taxation criterion should be the financial value of this wealth as the subject matter of motor vehicle tax (MVT) is the wealth owned. Collecting same rate of taxes from the taxpayers, who have the same power, within the scope of financial power principle will have a positive impact on income distribution, and will be more appropriate in terms of tax equity. Considering the practice in our country, income distribution might have a detrimental impact as the taxation is based on the qualities of the vehicle that is subject to tax, not on the financial power principle (Sugözü vd., 2014: 116).

\subsection{Effects of New Regulations in Motor Vehicle Tax}

The concept "vehicle value", which has entered into legislation with Article 22 of the "Law Amending Certain Tax Laws and Certain Other Laws" No. 7061, which entered into force on $28 / 11 / 2017$, and the consequent change in tariff no. (I) have brought along some criticisms. Of course, while providing a solution to various criticisms in the literature, continuance of the old tariff type for the vehicles registered before 31/12/2017 within the scope of provisional Article 8 has not been sufficient to eliminate all the criticisms.

As an example for the tariff no. (I) in terms of the passenger cars first registered in 2019 in our country; 
Table 1. Tax, $\mathrm{CO}_{2}$ and Vehicle Insurance Fees According to the Specifications of Some Vehicles - 2019

\begin{tabular}{|c|c|c|c|c|c|c|c|c|}
\hline Brand & Model & $\begin{array}{l}\text { Engine } \\
\text { Capacity }\end{array}$ & Year & $\begin{array}{l}\text { MVT } \\
\text { (TL) } \\
2019\end{array}$ & $\begin{array}{l}\text { Insurance } \\
\text { Value (TL) }\end{array}$ & $\begin{array}{l}\text { Vehicle } \\
\text { Value (TL) }\end{array}$ & $\begin{array}{l}\text { Type of } \\
\text { Fuel }\end{array}$ & $\begin{array}{c}\mathrm{CO}_{2} \\
\text { Emission } \\
\text { (gr/km) }\end{array}$ \\
\hline TOYOTA & $\begin{array}{c}\text { C-HR 1.2 TURBO } \\
\text { DIAMOND MULTIDRIVE } \\
\mathrm{S}\end{array}$ & 1200 & 2019 & 1.033 & 149.350 & $\begin{array}{l}\text { More than } \\
81.100\end{array}$ & Gasoline & 134 \\
\hline TOYOTA & $\begin{array}{l}\text { C-HR 1.8 HYBRID } \\
\text { DIAMOND PREMIUM } \\
\text { E-CVT }\end{array}$ & 1800 & 2019 & 5.003 & 199.750 & $\begin{array}{l}\text { Not more } \\
\text { than } \\
115.900\end{array}$ & $\begin{array}{l}\text { Gasoline \& } \\
\text { Hybrid }\end{array}$ & 86 \\
\hline AUDI & $\begin{array}{l}\text { A3 SPORTBACK } 1.0 \\
\text { TURBO DYNAMIC } \\
\text { STRONIC }\end{array}$ & 1000 & 2019 & 1033 & $\begin{array}{c}245.261 \\
(2018)\end{array}$ & $\begin{array}{l}\text { More than } \\
81.100\end{array}$ & Gasoline & 106 \\
\hline AUDI & $\begin{array}{l}\text { A3 SPORTBACK } 1.6 \text { TDI } \\
\text { DYNAMIC STRONIC }\end{array}$ & 1600 & 2019 & 1799 & $\begin{array}{c}282.407 \\
(2018)\end{array}$ & $\begin{array}{l}\text { More than } \\
81.100\end{array}$ & Diesel & 105 \\
\hline AUDI & $\begin{array}{l}\text { A5 COUPE } 2.0 \text { TFSI } \\
\text { QUATTRO DYNAMIC } \\
\text { STRAONIC }\end{array}$ & 2000 & 2019 & 5003 & $\begin{array}{c}613.989 \\
(2018)\end{array}$ & $\begin{array}{c}\text { More than } \\
115.900\end{array}$ & Gasoline & 135 \\
\hline BMW & i3 (170) (125 KW) & - & 2019 & 1.876 & $\begin{array}{c}342.700 \\
(2018)\end{array}$ & $\begin{array}{c}\text { More than } \\
144.800\end{array}$ & Electric & 0 \\
\hline
\end{tabular}

Source: We prepared the table based on the data collected from the official websites of brands, as well as from https://www.tsb.org.tr/kasko-deger-listesi.aspx?pagelD=631.

As it can be seen in the table above, the vehicle value, which is taken into account for the calculation of tax base with the new regulation, appears as a factor that might be affected by various types of discounts such as "year-end", "launch" or "employee discount". As this situation is on the contrary to the principles of equality and justice, and as the wording of the law (Article 2/20) is not clear, and unless an explanatory source regarding this definition is published, it is likely that this situation would cause various confusions for the taxpayers and sales representatives. In this context, it would be possible to prevent the possible confusions by preferring the objective vehicle insurance value rather than the subjective vehicle value, thus to prevent changing the tax base through various discounts at the dealers' discretion.

As an example through a vehicle registered in 2017 within the scope of the tariff no. (I/A); BMW $5.20 \mathrm{i}$ is produced in Germany with a minimum engine displacement of $2000 \mathrm{cc}$, while the same vehicle is available with $1600 \mathrm{cc}$ in Turkey. Thus, a regulation is required for offering the highincome group taxpayers an advantage to pay less tax, and allowing the manufacturers to make arrangements in their production lines. And this allows deducting an annual amount of 1.523 TL from the tax base in favor of the high-income taxpayers.

In addition to these, as $25 \%$ tax payment advantage, which is granted only for the vehicles with electric motor within the scope of the additional paragraph of Article 5, does not cover hybrid vehicles, this also causes unfairness for the taxpayers. Hybrid vehicles, which cause a less negative externality considering their $\mathrm{CO}_{2}$ emissions in terms of environmental protection as a constitutional liability, cannot benefit from any MVT advantage. Indeed, although they enjoy various tax cuts such as excise duty, this does not change the fact that the relevant situation 
does not give priority to the environmental purpose as the financial purpose of these indirect taxes remain at the forefront. For example, as seen in Table 1, a person who wants to buy a Toyota C-HR will have to pay approximately 5 times more tax than the gasoline model with the same specifications just because the vehicle value is higher when one owns a car that pollutes the environment less for various reasons. The fact that the emissions values are not taken into account in our country, with the highest number of criticisms in the literature, is becoming the main source of said injustices. As emphasized before, while there is a transition towards environment friendly MVT concept in the entire world, including the EU, the tariff in our country has to comply with the progressing tax legislation. In addition to this, there are a very few models meeting the conditions providing advantage to the electric motor vehicles. It is, however, clear that the relevant article will become more operational in terms of environmental protection when the number of electric motor vehicles increases in the future.

\subsection{Relationship of Motor Vehicle Tax and Environmental Protection Duty}

In contrast to other wealth taxes, a tax imposed on motor vehicles also includes a negative externality such as environmental pollution. It should be acknowledged that it is one of the duties of the state to determine a tax policy that minimizes the effects of externality. Article 56 of the Constitution says: It is the duty of the state and the citizens to improve the environment, protect the environmental health, and prevent environmental pollution." In this context, not taking the $\mathrm{CO}_{2}$ emission of the vehicles into account while determining the tax base is on the contrary to the environmental protection duty.

As a solution to this negative externality, the tax imposed on vehicles causing higher environmental pollution in terms of $\mathrm{CO}_{2}$ emissions is higher; on the contrary, the tax imposed on older vehicles according to the practices in Turkey is lower, and this causes a negative impact on the matter. The technology used in the production of older vehicles pollute the environment more, but they still pay less tax. Of course, it would cause a negative impact in terms of income distribution in tax when the tax base is solely determined based on emission; as the older vehicles (excluding the antique vehicles) belong to lower income groups due to their sales prices, it would cause further injustice in income distribution if harmful gas emission will be solely effective in tax base. In this context, there is a need for regulations where both the financial power principle and the environmental pollution are taken into account together.

\section{Motor Vehicle Tax in the European Union Within the Scope of Various Suggestions}

There is a more environmental trend in the taxation of motor vehicles in several EU member countries where the tax base is determined according to various factors such as vehicle age, weight, engine displacement etc., as well as $\mathrm{CO}_{2}$ emissions. For example, in Germany, registration date is an important factor as in the new regulation in our country. In this context, there is a dual distinction for the vehicles registered after July 1, 2009. $\mathrm{CO}_{2}$ emissions are taken as the basis for annual circulation tax, while $€ 2$ (gasoline) in $100 \mathrm{cc}$ and $€ 9.50$ (diesel) in $100 \mathrm{cc}$ distinction is taken into account for the basic tax. In addition to this, vehicles with an emission of less than $95 \mathrm{~g} / \mathrm{km}$ are excluded from the tax imposed on $\mathrm{CO}_{2}$ (European Automobile Manufacturers Association, 2018). In the UK, the annual tax for automobiles registered after March 2001 is similarly based on $\mathrm{CO}_{2}$ emissions. For standard automobiles, the amount varies from $\mathrm{f} 0$ (up to $100 \mathrm{~g} / \mathrm{km}$ ) to 
f 535 (above $255 \mathrm{~g} / \mathrm{km}$ ). Additionally, an additional tax is imposed on the vehicles which have their first registration since April 1, 2010. Rates range from $f 10$ (1-50 g/ $/ \mathrm{km})$ to $f 2,000$ (more than $255 \mathrm{~g} / \mathrm{km}$ ). The tax liability of corporate vehicles is also determined according to the $\mathrm{CO}_{2}$ emission values $(\mathrm{g} / \mathrm{km}$ ) and the type of fuel (Wappelhorst et al., 2018:38). In Finland, similarly, $\mathrm{CO}_{2}$ emissions are taken into account and rates range from 3.3\% to 50\%. Furthermore, within the scope of various rules between 2016 and 2019, discounts have been applied for vehicles with $\mathrm{CO}_{2}$ emissions of $141 \mathrm{~g} / \mathrm{km}$ or less (ACEA, 2018: 85).

As it is understood from the general practices of the EU, however, there is no common set of rules for all member countries, but the rules are generally related to $\mathrm{CO}_{2}$ emissions and weight. (Weight is important for the damage to be caused by the vehicles to the road). In Germany, Austria, Belgium, France, Slovenia and Spain, taxation is made by taking the amount of carbon dioxide per kilometer into account. In Belgium, for example, not only the emissions, but also the engine displacement and age are also taken into account as in our country. Likewise, carbon dioxide emissions as well as sales prices are effective in taxation in Greece (ACEA, 2018: 109). In Denmark, Finland, Ireland, Luxembourg, Malta, Portugal and the Netherlands, there is a combined taxation covering annual circulation in addition to registration (Rubik \& Mityorn, 2011). Although taking the vehicle value into account for the vehicles registered after 2018 has provided a solution to several criticisms in Turkey, it is unfortunately ignored that the motor vehicles pollute the environment more as they get older as they cannot keep up with the new technological developments, and nothing is reflected yet in the tariff schedules related to this (Yalçın, 2013: 142).

Considering the share of MVT revenues within the total wealth taxes, we see that it has a higher share in total revenues compared to the other wealth taxes. This result shows that it has an important place in providing justice in the income distribution and that the size of share is capable of meeting the expected result when applied together with effective regulation in line with various financial, social and environmental purposes.

In the literature, as there is no direct tax imposed on emission in Turkey, there are opinions advocating the necessity to consider environmental externality for MVT (Jamali, 2007: 302). In the European Union, MVT can be considered as a type of road and environmental tax, and in addition to the fuel consumption and engine displacement, the $\mathrm{CO}_{2}$ emission is also taken into consideration in determining the tax base (Sugözü vd., 2014:116). As it can be seen here, EU endeavors to provide both direct and indirect impact with various taxes to protect the environment. And this shows that MVT's purpose to protect the environment is in the forefront (Özdemir, 2009: 16). Although motor vehicle tax is considered as an environmental tax in several EU countries, it is listed among the wealth taxes in the Turkish tax system (Ömür \& Gerçek, 2017: 209), and there is no assessment criterion regarding the amount of emission in the MVT regulations.

\section{Conclusion}

Pursuant to the Law No. 7061, a tariff further taking financial power principle into consideration has been introduced with the amendment made in the Motor Vehicle Tax Law No. 197, but it is required to draw the lines of the concept "vehicle value" well and to develop control mechanisms preventing the reduction in tax base with the dealers' discretion. Additionally, as the former tariff is not repealed completely and is transferred to the provisional article 8 as the tariff no. (I/A) and the current practice still continues for the vehicles registered on 31/12/2017 and before, this situation prevents solving many of the criticisms available in the literature. 
Policies to prevent the environmental pollution, which are expected to have a greater impact on the legislations of all countries as a result of globalization, should also be taken into account in determining the tax base for MVT. Today, the share of environmental taxes is very limited in the total tax revenues globally, and they are generally collected as indirect taxes where the financial purpose is in the forefront. The importance of environmental taxes, however, has increased during the recent years. Particularly the concrete steps taken in developed countries prove this. One of the most concrete steps taken related to the environmental taxes is the effort to control negative externality in the taxation of motor vehicles in favor of environmental protection. Studies in the literature show that the $\mathrm{CO}_{2}$ emissions of the vehicles play a role in global warming. Therefore, while regulating the tariff for motor vehicle tax, it is important to constitute the legislation with a more environmentalist understanding.

\section{References}

ACEA, Tax Guide (2018). https://www.acea.be/uploads/news_documents/ ACEA_Tax _Guide_2018.pdf (25/02/2019).

European Automobile Manufacturers Association (2018). $\mathrm{CO}_{2}$ Based Motor Vehicle Taxes in the EU, https://www.acea.be/uploads/publications/CO2_tax_overview_2018.pdf (25/02/2019).

Jamali T. (2007). Ekolojik Vergiler (Çevre Vergileri), Yaklaşım Yayınevi, Ankara.

Oktar, A. (2018). Türk Vergi Sistemi, Türkmen Kitabevi, 2nd Edition, İstanbul.

Ömür Ö. M. \& Gerçek A. (2017). "Türkiye ve Avrupa Birliği Üyesi Ülkelerde Servet Vergilerinin Karşılaştırılması”, MCBÜ Sosyal Bilimler Dergisi, 15(2), Haziran, pp:197-216.

Öz E., Kutbay H. \& Buzkıran D. (2014). "Türk Servet Vergisi Sistemine Modern Bir Yaklaşım”, Gümrük Ticaret Dergisi, 2(4).

Özdemir B. (2009). "Küresel Kirlenme Sürdürülebilir Ekonomik Büyüme ve Çevre Vergileri”, Maliye Dergisi, Ocak-Haziran, N:156, pp:1-16.

Rubik F. \& Mityorn L. (2011). " $\mathrm{CO}_{2}$ Based Motor Vehicle Tax" Institute For Ecological Economis Research, https://azslide.com/co-2-based-motor-vehicle-tax_59ca0d731723 ddfd9d3 ab6b4.html (26/11/2018).

Sugözü i. H. \& Yıldırım H., Aydın H.i. (2014). "Vergi Adaleti Açısından Motorlu Taşıtlar Vergisinin Analizi", Selçuk Üniversitesi Sosyal Bilimler Dergisi, pp:115-128

Wappelhorst S., Mock P. \& Yang Z. (2018). “Using Vehicle Taxation Policy To Lower Transport Emissions An Overview For Passenger Cars in Europe", The International Council on Clean Transportation, Berlin.

Yalçın Z. (2013). "Potansiyel Bir çevre Vergisi Olarak Motorlu Taşıtlar Vergisi: Avrupa Birliği ve Türkiye Arasında Karşılaştırmalı Bir Analiz" Atatürk Üniversitesi iktisadi ve Idari Bilimler Dergisi, 27(2), pp:141-158. 